\title{
Generalizing Meaning-Making from One to Many: A Meso-Analytic Approach for Conceptualizing Group Constructive Development
}

\author{
John E. Barbuto, Jr. \\ Director, Center for Leadership \\ California State University Fullerton \\ USA \\ Megan Stevens \\ Global Leader of Talent Management \\ Corteva Agri science \\ USA
}

\section{ABSTRACT}

This essay presents the foundation for a group and team development model from a constructivist perspective. This model elevates Kegan's (1994) meaning-making theory to the meso level. Meaning-making involves not only the cognitive structure necessary to interpret the environment, but also encompasses interand intra-personal understanding, which, at the team level, is a social process that changes based on the members of the team. Several propositions are stated for further study.

\section{Introduction}

The organizational behavior field has seen an insurgence of work in group and team development (Gully \& Devne, 1995; Levy, 2005), resulting in increased practical attention to group level phenomena in the workplace. Before the recent shift toward group and team level dynamics, the primary organizational behavior focus was on individual and interpersonal levels of analyses. Tuckman's (1977) classic stages model of team development has survived the past 30 years without any consideration given to the individual team member, dynamics, interactions, or environment. Theoretical refinements and/or alternate conceptualizations are necessary to examine the complexities of the group and team dynamics today.

Tuckman's (1977) work focused on task performance at various stages of group development with little emphasis on stage progression. Gersick's (1988) punctuated equilibrium model explained how a team's development and performance depended on the midpoint of a task for motivation to complete the task. Others have studied team dynamics using variables such as task (Steiner, 1972), composition (Edwards, Day, Arthur, \& Bell, 2006), process and function (Sparrowe \& Liden, 1997), formation (Sheard \& Kakabadse, 2004), development (Tuckman, 1977), and time dependency (Gersick, 1989) related to group and team performance or process loss.

The team mental model research has greatly enhanced team understanding by focusing on team members' shared understanding of the task, team, equipment, and situation, but it overlooks the development of group cognition (Cannon-Bowers, Salas, \& Converse, 1993; Klimoski \& Mohammed, 1994; Shi \& Tang, 1997; Mohammed \& Dumville, 2001). Team meta-analysis also depended on cohesion-performance literature (Gully \& Devne, 1995). However, there is a great need in the field to examine how teams develop beyond their structural or process orientation (Kozolowski \& Ilgen, 2006). Newer models and research do not address how the team develops, instead of focusing on the structural or process orientation of a group or team (Kozolowski \& Ilgen, 2006; Hollenbeck, Ilgen, LePine, Colquitt, \& Hedlund, 1998; Bligh, Pearce, \& Kohles, 2006). The natural constructive development of teams has not been studied or conceptualized; such an effort would require a meso-analysis, as constructive development has only been conceptualized and studied at the individual level (Chapman, 1988; Kohlberg, 1981; Kegan, 1984).

The meso approach became widely recognized in the social sciences after Bandura (1982) elevated selfefficacy to the group level (collective efficacy). Rosseau (1985) and Klein and Kozlowski (2000) provide the theoretical foundation for meso-analytic work, which allows micro-level theories to be generalized to macro contexts. Other authors in the organizational behavior field use this model in learning theory (Bandura, 1982; Edmondson, 1999; Van den Bossche, Gijselaers, Segers, \& Kirschner, 2006) and efficacy (Bandura 1997, 2000). Examining constructive development in a macro context leads to a framework for group constructive development. 
Kegan (1982; 1994) described an adult constructive development model to examine how adults make meaning of the world around them, based on the cognitive constructive development initially explored in youth and adolescents (Piaget, 1959; Kohlberg, 1963). This approach involved consideration of principled and categorical thinking and included elements such as environmental embeddedness that generalize well to the group and team decision-making processes. Kuhnert and Lewis (1987) linked constructive development analysis with transformational leadership. Constructive development also has been used in understanding the thought processes of teachers (Berger, 2002; Hammerman, 2002), mothers (Madaras, 1999), and clergy (Gray, 1991; Guido, 1994; Kennard, 2002). It also has been applied to teaching (Boden, 2005; Drago-Severson, 2004), relationships (Byrne, Carr, \& Clark, 2004; De Dreu et al., 1995), family dynamics (Roy, 1993), and leadership (Corbett, 1995; Craig 1987; Hansberg, 1988). Exploring the potential for constructive development at the group level of analysis offers promising opportunities for research. Using mesoanalytic techniques to generalize from individual to group constructive development is as ambitious as it is needed in the group development field. This paper uses a mesoanalytic approach to propose stages of group constructive development.

\section{Constructive Development: Meso Considerations}

Constructive development was first proposed as a biological and sociological construct addressing the cognitive development of reasoning abilities among children and young adults. Piaget (1959) believed that cognitive development occurs through adaptation and organization. His model consisted of four stages of cognitive development: sensorimotor, preoperational, concrete, and operational. At the sensorimotor stage between birth and age two, individuals can learn only through physical activity, and memory is limited. At the preoperational stage, toddlers to early childhood, children acquire memory and imagination; however, they remain egocentric and illogical in their creation of reality. In the concrete stage, the child or adolescent can think logically, but cannot use symbols or conceptualize abstract objects. In the final, or operational, stage, the abstract can be conceptualized, categorized, mapped, and acted upon (Wood, Smith, \& Grossniklaus, 2001). Later studies concluded that adults also experience varying levels of formal operational thinking (Mines \& Kitchener, 1986). Adult cognitive construction is now examined from the adolescent, adult, and maturing adult perspectives (Schaie, 1996, 2005). Kegan (1982, 1994) summarizes the adult development process beyond a strictly cognitive model and uses the term meaning-making to explain it.

Meaning-making occurs through subject-object interaction, separateness, and integration. In subjectobject relations, a pattern of differentiation occurs. Individuals emerge from embeddedness in one way of thinking and are reintegrated into a new way of thinking. Subject-object relations are descriptors of reality embeddedness for the individual. Full comprehension of what is a subject and what is an object is necessary to understand constructive development.

Subjects are those things people are "identified with, tied to, fused with, or embedded in" (Kegan, 1994, p. 32). Objects are all things people can "reflect on, handle, look at, be responsible for, relate to each other, take control of, internalize, assimilate, or otherwise operate on" (Kegan, 1994, p. 32). When individuals can separate themselves from their context, the tension for growth is created; they can create greater meaning and challenge their place within this context.

Research also has explored how the environment affects physical cognition. Albert (1996) addressed the "holding power" of culture and concluded that culture can cause some stagnation of meaning-making, and, in some cases, higher levels of meaning-making are necessary to reflect on cultural effects. This research provides descriptions of constructive development and meaning-making at the individual level of analysis.

Hasegawa (2003) described constructive development as an epistemological order of consciousness in which role shifting occurs. As individuals grow, what was subject becomes the object (something they can reflect and act upon). In Kegan's (1994) model, meaning-making occurs through a combination of cognitive growth and the maturation of the interpersonal and intrapersonal. Constructive development is related to successful social interactions and positive social behaviors. It has been significantly associated with social perspective (Dixon, 1986) and social perspective-taking in writing situations (Hodgson,1990). Goodman (1983) demonstrated that couples at the same stage orientation had better communication. Other constructive development studies involving the family dynamic have been prescriptive in designing programs for improved decision making (Osgood, 1991) and boundary setting (Paravicini 2000). 
In a study of healthy families, Roy (1993) found a family organization principle that mirrored the individual constructive development model, indicating that the family organization principle centered on the child's organizing principle.

\section{Group or Team Cognition Development}

Roy's (1993) study, like studies and theories from a variety of fields such as organizational memory (Hanvanich, Sivakumar, \& Hult, 1997), socially shared cognition (DiMaggio, 1997), team learning (ZellmerBruhn \& Gibson, 2006), and team mental models (Kozlowski \& Ilgen, 2006), illustrates that a shared cognition or group cognition is created between members. This cognition is unique to the group and is a compilation of member cognitions.

Tuckman's (1977) model proposed that groups move through stages of forming, storming, norming, and performing. A forming group is developing its foundation, beginning to establish rules, and set initial goals. At the storming stage, the group engages in some sort of conflict to clarify relationships and mutual goals. At the norming stage, the group has a clear understanding of its goals and is making significant progress. Once a group has reached the performing stage it has a clear understanding of group norms, rules, and roles and displays seamless progression toward organizational goals.

Gersick (1988) conducted a phenomenological study of groups and discovered time was a significant motivational factor in team development. At the midpoint of a project, groups experience a transition in which new perspectives or thoughts change the direction of the group but help it move to a swift completion of the project, a phenomenon Gersick called "punctuated equilibrium." She found that if a group did not change its paradigm at this point, success was highly unlikely. Gersick's focus on time was different from other models, which focused on team agreement.

The focus on team agreement has been explored more recently in the mental model research in the group and team schemas (Klimoski \& Mohammed, 1994; Kozlowski, Gully, McHugh, Salas, \& Cannon-Bowers, 1996). Theorists have highlighted four-team cognition content areas used to evaluate consistency among members: equipment, task, team member, and teamwork (Cannon-Bowers, Salas, \& Converse, 1993). The construct is measured at the individual level and then assessed for consistency within the team. The team mental model proposes a clear measurement of team constructs; other models, like those that propose team learning effectiveness, have received less attention.

Van den Bossche, Gijselaers, Segers, and Kirschner (2006) proposed a three-step model of team effectiveness in learning environments: construction, coconstruction, and constructive conflict. The team first develops an understanding of the problem, then modifies or builds on its initial understanding of the model through group discussion. Finally, the team experiences positive constructive conflict to enhance its understanding of the problem. This model takes into account negotiation and role development among members in the larger team effectiveness. It attempts to explain the individual team member's role within the group, using the domains of psychological safety, interdependence, cohesion, group potency, and mutually shared cognition.

Effectiveness as evidence of collective cognition is studied in the organizational literature, but the group and team cognition are addressed in other literature as well. Additional evidence of group or team collective cognition can be found in research on aging adults. For example, a study of elderly adults (Strough \& Margrett, 2002) explored the concept of members creating meaning beyond their capacities by working together in groups. The authors examined long term pairing as a means for those with diminishing cognitive capabilities to use their collective abilities to overcome the obstacles associated with dementia.

To support the claim for collective or group cognition, scholars have researched how members are socialized into the group (Demoulin, Leyens, \& Yzerbyt, 2006). Others have examined how internal actions inform group behavior (Larson et al., 2002). A few team models, like Hackman and Wageman (2005), are role-specific and address how leaders of groups affect group behavior. While group and team cognition is a widely accepted concept, research explaining how this collective cognition changes, grows and develops at the group and team level is still in its infancy, lagging substantially behind the theoretical work (Mohammed and Dumville, 2001). An essential problem for researchers is the lack of agreement over how to assess cognition in teams. Testing the hierarchical integration between individuals and organizations requires meso-analysis (Sun, Coward, \& Zenzen, 2005). 


\section{Group Constructive Development}

Group constructive development mirrors Kegan's (1994) model of "meaning-making." Meaning-making involves not only the cognitive structure necessary to interpret the environment, but also encompasses inter and intra personal understanding, which, at the team level, is a social process that changes based on the members of the team. The stages of group constructive development have been named after the underlying structures that Kegan
(1994) uses to describe meaning-making at the individual level. Table one provides information about what is subject and objects at each meaning-making stage. The definitions are directly from Kegan's (1994) work. The types of group or team identified as "underlying structure" have been added to provide examples of groups or teams that may make meaning at a particular level.

Table 1: Stages of Group Constructive Development from Kegan's organizing structures

\begin{tabular}{|c|c|c|c|}
\hline $\begin{array}{l}\text { Kegan's } \\
\text { Stage }\end{array}$ & $\begin{array}{l}\text { Subject at } \\
\text { Individual level }\end{array}$ & $\begin{array}{l}\text { Object at } \\
\text { Individual level }\end{array}$ & Underlying Structure \\
\hline $\begin{array}{l}\text { Incorporative/ } \\
\text { Impulsive }\end{array}$ & $\begin{array}{l}\text { Impulses \& } \\
\text { Perceptions }\end{array}$ & $\begin{array}{l}\text { Reflexes } \\
\text { (sensing, moving) }\end{array}$ & $\begin{array}{l}\text { Single Point } \\
\text { Isolated self-sufficient cult } \\
\text { Isolated self-sufficient tribal } \\
\text { communities }\end{array}$ \\
\hline Imperial & $\begin{array}{l}\text { Needs, interests, } \\
\text { wishes }\end{array}$ & $\begin{array}{l}\text { Impulses, } \\
\text { perceptions }\end{array}$ & $\begin{array}{l}\text { Durable Category } \\
\text { Therapy groups } \\
\text { Competitive groups } \\
\text { Sports teams } \\
\text { Many leader-managed teams }\end{array}$ \\
\hline Interpersonal & $\begin{array}{l}\text { The interpersonal } \\
\text { mutuality } \\
\text { (expectations of } \\
\text { others/role) }\end{array}$ & $\begin{array}{l}\text { Needs, interests, } \\
\text { wishes }\end{array}$ & $\begin{array}{l}\text { Cross-Categorical } \\
\text { Trans-Categorical } \\
\text { Low or mid level } \\
\text { management teams } \\
\text { Project teams } \\
\text { Church boards }\end{array}$ \\
\hline Institutional & $\begin{array}{l}\text { Authorship, } \\
\text { identity, psychic } \\
\text { administration, } \\
\text { ideology }\end{array}$ & $\begin{array}{l}\text { The interpersonal } \\
\text { mutuality } \\
\text { (expectations of } \\
\text { others/role) }\end{array}$ & $\begin{array}{l}\text { System/Complex } \\
\text { Mid or high level } \\
\text { management teams (stretched) } \\
\text { Governmental leadership } \\
\text { teams (stretched) } \\
\text { Many shared leadership teams }\end{array}$ \\
\hline Inter-individual & $\begin{array}{l}\text { Inter-individuality, } \\
\text { inter-penetrability } \\
\text { of self systems }\end{array}$ & $\begin{array}{l}\text { Authorship, } \\
\text { identity, psychic } \\
\text { administration, } \\
\text { ideology }\end{array}$ & $\begin{array}{l}\text { Trans-System/Trans-Complex } \\
\text { Executive leadership teams }\end{array}$ \\
\hline
\end{tabular}

\section{Stage One: Single Point}

In Kegan's (1994) model, the impulsive stage occurs from birth to about age seven and draws from the sensorimotor and preoperational stages (Piaget, 1959). Early in this stage, individuals are not in control of their impulses or perceptions and are defined by them. They make sense of the world through their perceptions and can't fully consider another's perspective. At this stage the child knows only what can be tasted, touched, seen, heard, or felt and later begins to learn through the experience of others. Fantasy and impulses rule, and no consideration is given to others. By the end of this stage, impulse control develops, but the reason for controlling impulses remains external. According to Kegan, individuals in this stage are developing independent thinking and understanding that they exist. Movement and sensing can be thought about and reflected upon, but not much exists outside the individual at this stage.

At the single point stage of group constructive development, the group does not consider anything outside the group. Members begin to come together with a common interest or purpose and begin to sense that they 
are part of something. The group is beginning to develop an identity, albeit a very internal one; cognitively it knows only itself and doesn't acknowledge much beyond the group. The group or team is subject and the members are object. The group has some understanding of what parts make up the whole. Some groups that have a purpose but no interaction with a greater organization or system also may exist at the single point stage. For example, a geographically isolated cult group, or a selfsufficient tribal group that does not interact with outside organizations or individuals, are groups that would exist at the single point stage. Due to Hawthorne effect, an accurate observation of this stage is theoretically impossible; therefore, little research corresponds with this stage.

\section{Stage Two: Durable Category}

Kegan's (1994) imperial stage, or imperial balance, occurs in the preadolescent years and into adulthood for some. At this stage the individual can see as object not only the other's perspective, but his or her perspective as well. The individual views relationships as reciprocal and transactional, and mental organization begins to occur. Kegan refers to this organization as "durable categories" (1994 p. 21), which allow individuals to understand abstractions such as symbolism and ownership and to begin to experience empathy. As development of durable categories occurs, individuals begin to understand that other people have separate motivations, intentions, and perspectives. Durable categories are conceptually similar to cognitive learning (Neisser,1975), meaning (Barnard, Duke, Byrne, \& Davidson, 2007), or more generally, knowledge structures (Klimoski \& Mohammed, 1994). Although the individual at this stage can see another's perspective, he or she can consider that perspective only in terms of how it will affect him or her, and in this way is still highly egocentric. At this stage, the individual views the world through the lens of self-interest.

\section{At the durable category stage of group} constructive development, the group has some interaction with the external environment and must make some decisions about it. However, understanding of the external environment is still limited; the group has little effect on its environment, so there is little need to consider where the group fits within it. This structure is similar to concepts within Social Network Theory (SNT) (Granovetter, 1974; Balkundi \& Kilduff, 2006). At the durable category stage, team members may have links outside their group, but do not need to access them. Similarly, while the members serve their purpose within the group, they are not nodes for others outside the group. An example of a group at this stage is an Alcoholic Anonymous group.

According to traditional models like Tuckman's (1977), which was based on research with therapy groups, durable category groups and teams would continue to develop and grow; but under group constructive development, only certain aspects of group cognition develop, depending on the purpose of the group. In a therapy group the purpose is for members to work on individual development within the group. The group may experience some inter-development, but never any intra-development, which is necessary for group constructive development. Like an AA group, an externally managed team would likely function at this level. The team would have little need to make meaning of the external environment, as the manager already sets this context for the team. As in Kegan's (1994) individual model, the team can reflect on its impulses and perceptions, but is unable to articulate its own needs, interests, or wishes.

Like an individual at Kegan's (1994) second stage, a group at this stage cannot empathize with other groups, teams, or aspects outside its current situation. Another example of a group or team functioning at the durable category stage is a low performing athletic team. The team is focusing all practices on improving the strengths of the team and developing talent within the team. Its strategy going into the next game is to "do its best!" As important as team practice is, however, there are aspects the team does not think to practice or cannot consider yet, such as studying the other team's strengths and weaknesses and creating a strategy for adjusting plays to counter the opponent's strategy.

As the team develops into the durable category stage, it may internally master enough skills to consider the strategy of its opponent. The push or pull into development depends on the environment, and for this reason many groups pass through this stage quickly as they organize around their tasks. The group must be able to collectively empathize and consider the needs and motivation of other groups. If the athletic team decides to change its strategy and study the opponent a week before they play because the athletic director has recommended that they should, they are operating at a durable category stage. If they change their strategy because a team 
member has stepped up to act as leader, the team may be on its way to the next stage of development. The leader is exhibiting higher meaning making abilities and the rest of the team may follow and reach the cross-categorical stage.

\section{Stage Three: Cross-Categorical.}

Kegan's (1994) third stage, the interpersonal stage, occurs post-adolescence for many, but many adults do not reach this stage. At the interpersonal stage, the individual is subject to and embedded in interpersonal relationships, and his or her needs, wants, and desires are objects. Individuals at this stage have a high sense of empathy, and thinking at this stage is much more logical. A move occurs from durable categories to crosscategorical knowing, enabling individuals to predict how their actions will influence relationships with others; such a prediction can be highly motivating. Identity for individuals at this stage is "subjective and self-conscious" (Kegan, 1994, p. 95).

At the cross-categorical stage of group constructive development, members of the group can reflect on the group's needs and wants and hold these separate from themselves, but the team is governed by its role and other imposed expectations. A project team is likely to be making meaning at this level. The team members are meeting specific deadlines, usually imposed by others, and coordinating with each other, while taking into consideration the complexities of the greater environment. The team makes rules to deal with the external complex environment, but does this only to meet its role and deadline expectations. While a project team may want to produce a product one way to achieve the goals of the overall project, it is continually checking in with either a supervisor or client to make sure that it is meeting the external expectations. The project team identity is authored outside the team.

A mid-level management team also may settle into group constructive development at the cross-categorical stage. This team is easily recognized for continually reading the latest management book and trying to implement the newest practices. Implementation of new knowledge is likely to meet with failure more often than success, due to the inability of the group to distinguish itself from the latest research recommendation. Kegan refers to this phenomenon as one of the natural pulls of consciousness, the desire to belong, as well as the desire to be separate and unique. The group wants to be part of the organization, but distinct for what it brings to the table. At this level of group cognition, the team knows there is an external environment to which it needs to adjust its way of knowing, but remains a half step behind in implementing change. This team can reflect on its needs, desires, and wants, but is so embedded in other's expectations it cannot recognize how it is driven by external expectations.

\section{Stage Four: System Complex}

Kegan (1994) speculates that over half of the adult population never reaches the institutional stage, at which individuals can see relationships with others as object and at which they have a set of guiding principles to aid in decision making. Individuals at this stage are object to the identity they have developed and subject to the self that they create. While their decision making principles are not influenced by external sources or relationships, individuals still can be empathetic in reflecting on the experience of others.

A team or group at the fourth stage of development is at the system complex stage and is no longer embedded in its self-knowing as others expect it to be. The team can perceive as object the interpersonal (or inter organizational) mutuality and can distinguish the expectations of others from the expectations of the group. Some project or task groups may reach this level, but in many cases the team or group plays a service role and cannot collectively understand how it can author its expectations while serving the client, organization, subordinates, etc.

This level may naturally be achieved by a governing group such as a legislative group or team. By nature, this type of team is self-authoring and creates governing rules for itself. The group must take into consideration the expectations of the external environment but is not embedded in the expectations of its constituents. Following this model of meaning making, it is expected that the nature of a governing team is to evaluate the internal and external environments and make decisions and take action based on principles it has established.

Kegan (1994) outlines clearly what an individual operating at stage four would be like, and a team would operate similarly. At this stage, members can manage boundaries, be the inventors of their work, conceive of the organization as a whole, see their relationships to the whole, and see the relationship of the parts to the whole. 


\section{Stage Five, Trans-System/Trans-Complex}

At Kegan's (1994) inter-individual stage, individuals are subject to their interdependence, and they perceive their self-authorship or ideology as object. Because individuals at this stage are embedded in their interdependence, there is a high comfort level with being part of a complex and changing system.

At the trans-system/trans-complex stage of group constructive development, the group sees its selfauthorship as object, is subject to fluidity, and can conceptualize itself as both separate from and part of the external environment. The collective diagnosis of problems and issues is continually changing the group's conceptualization. As in other models where the team's highest level is adaptability (Kozlowski \& Salas, 1997), in the Kegan meso-model, the highest level of development depends on reaction to the environment. Van de Ven and Poole (2005) indicated change is usually stressful to members and groups (also described by Marion and Uhl-Bein [2001] as resonance). However, at this highest level of team development, reaction to the environment is not forced or stressful; decision making regarding the external environment is not a discussion point because the group is embedded in the external environment.

The following propositions explore the conditions and indicators of group constructive development.

\section{Propositions}

An antecedent for group constructive development is a need for some sort of in-group interaction causing a group level decision to be made. In this decision the group must have some interaction with an external system or group.

$\boldsymbol{P}$ 1: Group constructive development will occur most often when groups interact with their environment.

$P$ 2: Groups that exist in a silo will be less likely to experience group constructive development.

Other research has demonstrated that leader influence is an important factor in group and team development. Hambrick and Mason's (1984) Upper Echelons Theory brought to light the significance of top management teams (TMTs) within organizations. They proposed, and subsequent researchers demonstrated (i.e. Finkelstein \& Hambrick, 1990), that the organization is a reflection of its top leaders. Zaccaro and Banks (2001) proposed a model based on leader performance functions and the mutual influence between leaders and their team members. Hackman and Wageman (2005) demonstrated that the leader's team design and coaching determined team performance levels. Additionally, similarity principles and team fit research indicate that members prefer to work with others like them and prefer leaders with some outstanding qualities and abilities (KristofBrown, Barrick, \& Stevens, 2005), as described in the idealized influence stage of transformational leadership (Bass, 1996).

P3: Leader stage of constructive development is related to team stage of constructive development.

P4: The relationship between leader stage of constructive development and group constructive development will be enhanced or neutralized by followers' stages of constructive development.

Shared leadership models and research indicate that there may not be a continually distinguishable leader of the group or team and that various members of the team hold the position of leader at various times (O’Toole, 2002; Bligh, Pearce, \& Kohles, 2006; Klein, Ziegert, Knight, \& Yan, 2006). In the group constructive development model, the team leader may not be the most powerful or influential member of the team. An individual with higher amounts of reward, coercive, expert or reverent power may influence how the group performs (Raven \& French, 1958).

According to the literature on individuals, adjusting to complexity in the environment provides a competitive advantage to leaders. Stratified Systems Theory (Jacobs \& Jaques, 1990) addressed cognitive abilities of individuals in organizations. The higher one progresses in an organization, the more complex the tasks, and thus the higher the cognitive capacity and ability a leader must possess. Cognitive power and cognitive capacity were introduced as predictors of individual success in a complex leadership environment, with speculation that mental models are created to make meaning of complex situations. These models give the thinker the ability to integrate numerous experiences and develop strategic responses to current problems and issues. Other authors have described leadership behavioral requirements in a complex domain and the implications of leading in complex environments (Denison, Heart, \& Kahn, 1996; Ireland \& Hitt, 2005).

P 5: A group's constructive development stage will rarely exceed the individual constructive development stage of the leader (formal or informal). 
P 6: There will be a positive relationship between group performance and the stage of group constructive development.

The group constructive development model is founded in the individual development model. As the team progresses through the model in an "upward motion," development follows the individual model, but in the individual model, regression is not common. At the team and group level, however, regression could occur quickly depending on the dynamic and makeup of the group. The attraction-selection-attrition (ASA) model has been successfully interpreted across levels (Ployhart, Weekley, \& Baughman, 2006). This model can inform how group constructive development may encounter stage progression-regression patterns based on membership. In this way, group constructive development is a trait and state. Measured over extended periods, the group constructive development stage may not show significant variance, but at periods of membership change, variance in stage will be more likely to occur.

$P$ 7: Groups' constructive development will progress sequentially, but may regress non-sequentially.

$P$ 8: Group or team member turnover may alter the stage of group constructive development.

$P$ 8a: In instances where the majority of the group is at a stage similar to that of the leaving member, there will be little change in group constructive development.

$\boldsymbol{P}$ 8b: In instances where the majority of the group is at a stage above or below that of the exiting member, there will be significant change in group constructive development.

$P$ 8c: In instances where the majority of the group is at a stage above or below that of the exiting member, and the exiting member is a leader (formal or informal), there will be the greatest change in group constructive development.

Membership changes in the group affect the state of group constructive development; likewise, the group affects individual members. Jackson and Lepine (2003) have demonstrated that lower performers in teams are compensated for, motivated, trained, or rejected. If a member who is brought into the team is at a stage of meaning making lower than that of the rest of the group or team, he or she will learn to think or make meaning like the other members.

P 9: Group constructive development will imitate individual stage progression.
Group constructive development mirrors Kegan's stages of individual development. Considerations in measuring this theory and contributions to the field are discussed further below.

\section{Discussion}

Considerations, Measurement of Group Constructive Development

Measurement of group constructive development should occur at a purely meso level, reflecting the voice of the group or team, using measurement options similar to Kegan's measurements of individual meaning making. Existing bodies of literature and constructs can be drawn upon for full measurement of group constructive development at the meso level. In some instances, the stage of group constructive development is measured by the process the group or team performs to achieve goals. To extend the discussion on cognitive stage development of the team or group, it is important to consider some aspects of structure, such as level of measurement. According to Kelin and Kozlowski's (2000) Multi-Level theory, the group or a team is considered a unit in and of itself. In measuring group constructive development, the group is measured by consensus rather than by aggregation. Using Rousseau's (1995) definitions for level of measurement and analysis, both should occur at the group level, with some measurement at the individual level to confirm or deny the above propositions. Therefore, group constructive development should be measured by meaning making at the group levels corresponding to the levels outlined by Kegan and Lahey (1984) for individuals. Additionally, aspects of measurement from other team development models may be useful (Naumann \& Bennett, 2000; Bligh, Pearce, \& Kohles, 2006).

Tacit knowledge is that portion of the group or team knowledge base that cannot be defined (Polanyi, 1966; Subramaniam \& Venkatraman,2001). If we think of group constructive development as tacit knowledge, development of measures outside the Kegan interview will be more difficult. While tacit knowledge is an aspect of the group or team dynamic that cannot be explained or measured, meaning making is the composite collective consciousness of the group measured holistically. Group meaning making built on subject-object relations encompasses the inter and intra-development of the team. Measuring meaning making includes cognitive development as demonstrated by knowledge and skill development, but also thought and emotional movement 
of the group or team. Kegan (1994) uses the term embeddedness or movement from embeddedness, a term also used in the team and organizational research fields (Uzzi, 1997). This may be one area to examine in measurement development. Likewise, adaptive structure (Kozlowski et al. 1996) is a construct that seems to be highly related to the higher levels of Kegan's (1994) meaning making.

Embeddedness has been described as the "ongoing contextualization within the social structure" (Dacin, Ventresca, \& Beal, 1999), which is similar to definitions of adaptive structure in teams (Day, Gronn, \& Salas, 2004; Ford \& Seers, 2006; Burke, et al., 2006). Others like Schneider and Somers (2006) have argued that adaptive structures are necessary to navigate the complex environments groups and teams must face. According to the stages of progression in group constructive development, a team that develops an adaptive structure has reached the highest level of meaning making, demonstrative of the trans-systemcomplex stage (stage 5). At this stage, change has a symbiotic relationship with the structure of the team, and the structure of the group is conducive to the complexity to the environment.

In addition to identifying measurable structures of group constructive development, most group or team research considers interdependence of members. Highly interdependent groups and teams are more successful (Katz-Navon \& Erez, 2005). Since group constructive development is a broad model, interdependence may vary at the different stages due to the type of group or team under study. One reason the model is described for both groups and teams is that they both fall into the development model, with teams existing as a higher level functioning group. Interdependence may fit into the group constructive development model following further research.

\section{Contributions}

Group constructive development brings the research to a new level in assessing the stages of group development. Newer development models like Wheelan and McKeage's (1993) still heavily mirror Tuckman's (1977) broad model, but this paradigm of development has nearly exhausted the opportunities for understanding group and team growth. In addition to contributing to the group and team development literature, group constructive development provides opportunities for research in leadership, member development, and group and team decision making. Group constructive development also could contribute to greater understanding of team operations in organizations.

Duchon, Ashmos, and Nathan (2000) use the term sensemaking to describe the purpose of teams within organizations. In many ways, sensemaking from a systems standpoint is similar to meaning making on an interpersonal level. If teams and groups are to make sense of complex environments, the level at which they do so could have significant organizational implications. Group constructive development proposes levels of meaning making for groups or teams that will be useful in studying group and team sensemaking.

Pearce and Sims (2002) argue that leadership can be a shared group level phenomenon and that shared leadership is a determinant of group outcomes. Research and theory development have just begun to examine how shared leadership develops in groups and teams (Yang \& Tang, 2004; Klein, Ziegert, Knight, \& Yan, 2006); a group and team meaning making theory will enhance this area.

\section{Summary}

This essay has presented the foundation for a group and team development model from a constructivist perspective. This model elevates Kegan's (1994) meaning making theory to the meso level. There is precedent for elevating an individual level construct to the group or team level, and group constructive development meets similar criteria. Several propositions have been stated for further study and use of such a model has the potential to contribute to research in the content areas of groups and teams, leadership, and organizations.

\section{References}

Albert, S. P. (1996). Revolutionary loyalists: A psychological study of American Catholic feminists. (Doctoral dissertation, California Institute of Integral Studies, 1996). DAI, 57 (04B), 160-2853.

Balkundi, P., \& Kilduff, M. (2006). Erratum to "The ties that lead: A social network approach to leadership". The Leadership Quarterly 16 (2005), 941-961. 
Bandura, A. (2000). Exercise of human agency through collective efficacy. Current Directions in Psychological Science, 9(3), 75-78.

Bandura, A. (1982). The self and mechanisms of agency. In J. Suls (Ed.), Psychological perspectives on the self (vol.1). Hillsdale, NJ: Erlbaum.

Bandura, A. (1997). Self-efficacy: The exercise of control. New York: W.H. Freeman.

Barnard, P. J., Duke, D. J., Byrne, R. W., \& Davidson, I. (2007). Differentiation in cognitive and emotional meanings: An evolutionary analysis. Cognition \& Emotion, 21(6), 1155-1183.

Bass, B. M. (1996). New paradigm of leadership: An inquiry into transformational leadership. Alexandria, Va.: U.S. Army Research Institute for the Behavioral and Social Sciences.

Berger, J. G. (2002). Exploring the connection between teacher education practice and adult development theory. (Doctoral dissertation, Harvard University, 2002). DAI, 63 (06A), 256-2202.

Bligh, M. C., Pearce, C. L., \& Kohles, J. C. (2006). The importance of self- and shared leadership in team based knowledge work. Journal of Managerial Psychology, 21(4), 296-318.

Boden, C. J. (2005). An exploratory study of the relationship between epistemological beliefs and self-directed learning readiness. (Doctoral dissertation, Kansas State University, 2005. DAI, 66 (04A), 425-1241.

Burke, C. S., Stagl, K. C., Salas, E., Pierce, L., \& Kendall, D. (2006). Understanding team adaptation: A conceptual analysis and model. Journal of Applied Psychology, 91(6), 1189-1207.

Byrne, M., Carr, A., \& Clark, M. (2004). Power in relationships of women with depression. Journal of Family Therapy, 26(4), 407-429.

Cannon-Bowers, J. A., Salas, E., \& Converse, S. (1993). Shared mental models in expert team decision making. In N. Castellan (Ed.), Individual and group decision making (1st ed., pp. 221-221-246). Hillsdale: Lawrence Erlbaum Associates.

Chapman, M. (1988). Constructive evolution : Origins and development of Piaget's thought. Cambridge England; New York: Cambridge University Press.

Corbett, R. P., Jr. (1995). Managerial style as a function of adult development stage. (Doctoral dissertation, University of Massachusetts, 1995). DAI, 56 (03A), 169-794.

Craig, E. E. (1987). A field study of adult development: Developing leaders in a citizen' action organization (Citizens' action organization). (Doctoral dissertation, Boston University, 1987). DAI, 53 (08B), 314-4391.

De Dreu, C. K. W., Nauta, A., \& Van de Vliert, E. (1995). Self-serving evaluations of conflict behavior and escalation of the dispute. Journal of Applied Social Psychology, 25(23), 2049-2066.

Dacin, M. T., Ventresca, M. J., \& Beal, B. D. (1999). The embeddedness of organizations: Dialogue \& directions. Journal of Management, 25(3), 317-356.

Day, D. V., Gronn, P., \& Salas, E. (2004). Leadership capacity in teams. Leadership Quarterly, 15(6), 857-880.

Demoulin, S., Leyens, J., \& Yzerbyt, V. (2006). Lay theories of essentialism. Group Processes \& Intergroup Relations, 9(1), 25-42.

DiMaggio, P. (1997). Culture and cognition. Annual Review of Sociology, 23, 263-287.

Dixon, J. W. (1986). The relation of social perspective stages to Kegan's stages of ego development and factors related to discrepancy patterns. (Doctoral dissertation, University of Toledo, 1986). DAI, 47 (12A), 127-4324.

Drago-Severson, E. (2004). Becoming adult learners: Principles and practices for effective development. New York: Teachers College Press.

Duchon, D., Ashmos, D., \& Nathan, M. (2000). Complex systems \& sensemaking teams: Conflict, connectedness, \& leadership. In M. Beyerlein, D. Johnson, \& S. Beyerlein (Eds.), Team performance management. JAI Press Inc. 
Edmondson, A. (1999). Psychological safety and learning behavior in work teams. Administrative Science Quarterly, 44(2), 350-383.

Edwards, B. D., Day, E. A., Arthur, W., \& Bell, S. T. (2006). Relationships among team ability composition, team mental models, and team performance. Journal of Applied Psychology, 91(3), 727-736.

Finkelstein, S., \& Hambrick, D. C. (1990). Top-management-team tenure and organizational outcomes: The moderating role of managerial discretion. Administrative Science Quarterly, 35(3), 484-503.

Ford, L. R., \& Seers, A. (2006). Relational leadership and team climates: Pitting differentiation versus agreement. Leadership Quarterly, 17(3), 258-270.

Gersick, C. J. G. (1988). Time and transition in work teams: Toward a new model of group development. Academy of Management Journal, 31(1), 9-41.

Gersick, C. J. G. (1989). Marking time: Predictable transitions in task groups. Academy of Management Journal, 32(2), 274-309.

Goodman, R. G. (1983). A developmental and systems analysis of marital and family communication in clinic and non-clinic families: A way to see the parts and the whole. (Doctoral dissertation, Harvard University, 1983). DAI, 44 (05B), 555-1593.

Granovetter, M. S. (1974). Getting a job: A study of contacts and careers. Cambridge, MA: Harvard University Press.

Gray, J. L. (1991). Meaning as an assessment category for pastoral counseling. (Doctoral dissertation, The Southern Baptist Theological Seminary, 1991). DAI, 52 (03A), 258-966.

Guido, J. J. (1994). Schooling the soul: The psychological nature and function of god images among Roman Catholic seminarians. (Doctoral dissertation, Harvard University, 1994). DAI, 55 (07A), 284-2006.

Gully, S. M., \& Devine, D. J. (1995). A meta-analysis of cohesion and performance. Small Group Research, 26(4), 497.

Hackman, J. R., \& Wageman, R. (2005). A theory of team coaching. Academy of Management Review, 30(2), 269287.

Hambrick, D. C., \& Mason, P. A. (1984). Upper echelons: The organization as a reflection of its top managers. The Academy of Management Review, 9(2), 193-206.

Hammerman, J. K. (2002). Experiencing professional development : A constructive-developmental exploration of teachers' experiences in A mathematics teacher professional development program. (Doctoral dissertation, Harvard University, 2002). DAI, 63 (06A), 278-2217.

Hanvanich, S., Sivakumar, K., \& M. Hult, G. T. (2006). The relationship of learning and memory with organizational performance: The moderating role of turbulence. Journal of the Academy of Marketing Science, 34(4), 600-612.

Hasegawa, B. A. (2003). The teacher leader role shift: A constructive-developmental study of teacher leaders' experiences of role transition and authority relationships. (Doctoral dissertation, Harvard University, 2003). DAI, 64 (08A), 262-2721.

Yang, H. \& Tang, J. (2004). Team structure and team performance in IS development: A social network perspective. Information \& Management, 41(3), 335-349.

Hodgson, T. O. (1990). Constructive developmental analysis of autobiographical writing. (Doctoral dissertation, University of Massachusetts, 1990). DAI, 51 (11A), 214-3674.

Hollenbeck, J. R., Ilgen, D. R., LePine, J. A., Colquitt, J. A., \& Hedlund, J. (1998). Extending the multilevel theory of team decision making: Effects of feedback and experience in hierarchical teams. Academy of Management Journal, 41(3), 269-282.

Ireland, R. D., \& Hitt, M. A. (2005). Achieving and maintaining strategic competitiveness in the 21st century: The role of strategic leadership. Academy of Management Executive, 19(4), 63-77. 
Jackson, C. L., \& LePine, J. A. (2003). Peer responses to a team's weakest link: A test and extension of LePine and Van Dyne's model. Journal of Applied Psychology, 88(3), 459-475.

Jacobs, T. O., \& Jaques, E. (1990). Military executive leadership. In K. E. Clark, \& M. B. Clark (Eds.), Measures of leadership. West Orange, NJ: Leadership Library of America, Inc.

Katz-Navon, T. Y., \& Erez, M. (2005). When collective and self-efficacy affect team performance: The role of task interdependence. Small Group Research, 36(4), 437-465.

Kegan, R., \& Lahey, L. (1984). Adult leadership \& adult development: A constructivist view. In B. Kellerman (Ed.), Leadership: Multidisciplinary perspectives (pp. 200-200-250). Englewood Cliffs, NJ: Prentice-Hall.

Kegan, R. (1982). The evolving self: Problem and process in human development. Cambridge, MA: Harvard University Press.

Kegan, R. (1994). In over our heads: The mental demands of modern life. Cambridge, MA: Harvard University Press.

Kennard, L. J. (2002). A constructive developmental examination of clergy leadership behavior. (Doctoral Dissertation. Trinity Evangelical Divinity School, 2002). DAI 63 (04A), 345-1398.

Klein, K. J., \& Kozlowski, S. W. J. (2000). From micro to meso: Critical steps in conceptualizing and conducting multilevel research. Organizational Research Methods, 3(3), 211.

Klein, K. J., Ziegert, J. C., Knight, A. P., \& Xiao, Y. (2006). Dynamic delegation: Shared, hierarchical, and deindividualized leadership in extreme action teams. Administrative Science Quarterly, 51(4), 590-621.

Klimoski, R., \& Mohammed, S. (1994). Team mental model: Construct or metaphor? Journal of Management, 20(2), 403.

Kohlberg, L., (1981). The meaning and measurement of moral development. Worcester, MA: Clark University Press.

Kohlberg, L. (1963). The development of children's orientations toward a moral order. I. sequence in the development of moral thought. International Journal of Human Development. 6, 11-33.

Kozlowski, S. W. J., \& Salas, E. (1997). An organizational systems approach for the implementation and transfer of training. In K. J. Ford, S. W. J. Kozlowski, \& K. J. Klein (Eds.), Improving training effectiveness in work organizations. Mahwah, NJ: Lawrence Erlbaum Associates.

Kozlowski, S. W. J., Gully, S. M., McHugh, P. P., Salas, E., \& Cannon-Bowers, J. A. (1996). A dynamic theory of leadership and team effectiveness: Developmental and task contingent leader roles. In G. R. Ferris (Ed.), Research in personnel and human resources management (pp. 253-253-305). Greenwich, CT: JAI Press.

Kozlowski, S. W. J., \& Ilgen, D. R. (2006). Enhancing the effectiveness of work groups and teams. Psychological Science in the Public Interest, 7(3), 77-124.

Kristof-Brown, A., Barrick, M. R., \& Stevens, C.K. (2005). When opposites attract: A multi-sample demonstration of complementary person-team fit on extraversion. Journal of personality, 73(4), 935-958.

Kuhnert, K. W., \& Lewis, P. (1987). Transactional and transformational leadership: A constructive/developmental analysis. The Academy of Management Review, 12(4), 648-657.

Larson, J. R., Sargis, E. G., Elstein, A. S., \& Schwartz, A. (2002). Holding shared versus unshared information: Its impact on perceived member influence in decision-making groups. Basic \& Applied Social Psychology, 24(2), $145-155$.

Levy, O. (2005). The influence of top management team attention patterns on global strategic posture of firms. Journal of Organizational Behavior, 26, 797-819.

Madaras, E. I. (1999). Journeys inward: Portraits of three women's growth through the entry into motherhood (Psychological transformation, orders of consciousness, self definition). (Doctoral dissertation, Harvard University, 1999). DAI, 60 (06B), 273-3002.

Marion, R., \& Uhl-Bien, M. (2001). Leadership in complex organizations. Leadership Quarterly, 12(4), 389. 
Mines, R., A., \& Kitchener, K., S. (1986). Adult cognitive development: Methods and models. New York: Praeger.

Mohammed, S., \& Dumville, B. C. (2001). Team mental models in a team knowledge framework: Expanding theory and measurement across disciplinary boundaries. Journal of Organizational Behavior, 22(2), 89-106.

Naumann, S. E., \& Bennett, N. (2000). A case for procedural justice climate: Development and test of a multilevel model. Academy of Management Journal, 43(5), 881-889.

Neisser, U. (1975). Self-knowledge and psychological knowledge: Teaching psychology from the cognitive point of view. Educational Psychologist, 11(3), 158.

Osgood, C. N. (1991). Readiness for parenting teenagers: A structural developmental approach (constructivist). (Doctoral dissertation, University of Massachusetts, 1991). DAI, 52 (06B), 210-3319.

Paravicini, S. F. (2000). Parent-child attunement therapy: Development of a program for children one to three years old. (Doctoral dissertation, California School of Professional Psychology - Berkeley/Alameda, 2000). DAI, 60 (09B), 115-4901.

Pearce, C. L., \& Sims, H. P. (2002). Vertical versus shared leadership as predictors of the effectiveness of change management teams: An examination of aversive, directive, transactional, transformational, and empowering leader behaviors. Group Dynamics: Theory, Research, and Practice, 6, 172-172-197.

Piaget, J., (1959). The language and thought of the child. New York: Humanities Press.

Ployhart, R. E., Weekley, J. A., \& Baughman, K. (2006). The structure and function of human capital emergence: A multilevel examination of the attraction-selection-attrition model. Academy of Management Journal, 49(4), 661677.

Polanyi, M. (1966). The logic of tacit inference. Philosophy, 41(155), 1-18.

Raven, B. H., \& French, J. R. P., Jr. (1958). Legitimate power, coercive power, and observability in social influence. Sociometry, 21(2), 83-97.

Rousseau, D. M., (1985). Issues of level in organizational research: Multilevel and cross-level perspectives. In L. L. Cummings \& B. M. Staw (Eds.), Research in organizational behavior (pp. 1-37). Greenwich, CT: JAI Press.

Roy, N. S., (1993). Toward an understanding of family functioning: An analysis of the relationship between family and individual organizing principles. (Doctoral dissertation, Harvard University, 1993). DAI, 54 (05B), 1972787.

Schaie, K. W. (1996). Intellectual development in adulthood: The Seattle longitudinal study. Cambridge [England]; New York: Cambridge University Press.

Schaie, K. W. (2005). Developmental influences on adult intelligence: The Seattle longitudinal study ([Update] ed.). New York: Oxford University Press.

Schneider, M., \& Somers, M. (2006). Organizations as complex adaptive systems: Implications of complexity theory for leadership research. Leadership Quarterly, 17(4), 351-365.

Sheard, A. G., \& Kakabadse, A. P. (2004). A process perspective on leadership and team development. Journal of Management Development, 23(1), 7-106.

Shi, Y., \& Tang, H. K. (1997). Team role behaviour and task environment. Journal of Managerial Psychology, 12(1), 85 .

Sparrowe, R. T., \& Liden, R. C. (1997). Process and structure in leader-member exchange. Academy of Management Review, 22(2), 522.

Steiner, I. D., (1972). Group process and productivity. New York: Academic Press.

Strough, J., \& Margrett, J. (2002). Overview of the special section on collaborative cognition in later adulthood. International Journal of Behavioral Development, 26(1), 2-5.

Subramaniam, M., \& Venkatraman, N. (2001). Determinants of transnational new product development capability: Testing the influence of transferring and deploying tacit overseas knowledge. Strategic Management Journal, 22(4), 359-378. 
Sun, R., Coward, L. A., \& Zenzen, M. J. (2005). On levels of cognitive modeling. Philosophical Psychology, 18(5), 613-637.

Tuckman, B. W., \& Jensen, M. A. C. (1977). Stages of small-group development revisited. Group Organization Management, 2(4), 419-427.

Uzzi, B. (1997). Errata: Social structure and competition in interfirm networks: The paradox of embeddedness. Administrative Science Quarterly, 42(2), 417-418.

Van de Ven, A. H., \& Poole, M. S. (2005). Alternative approaches for studying organizational change. Organization Studies (01708406), 26(9), 1377-1404.

Van den Bossche, P., Gijselaers, W. H., Segers, M., \& Kirschner, P. A. (2006). Social and cognitive factors driving teamwork in collaborative learning environments: Team learning beliefs and behaviors. Small Group Research, 37(5), 490-490-521.

Wheelan, S. A., \& McKeage, R. L. (1993). Developmental patterns in small and large groups. Small Group Research, 24(1), 60.

Wood, K. C., Smith, H., \& Grossniklaus, D. (2001). Piaget's stages of cognitive development . Emerging perspectives on learning, teaching, and technology. Orey, $M$ (Ed.) Retrieved 7.25 .07 from http://projects.coe.uga.edu/epltt/

Zaccaro, S. J., \& Banks, D. J. (2001). Leadership, vision, and organizational effectiveness. In S. J. Zaccaro \& R. J. Klimoski (Eds.) The Nature of organizational leadership (pp. 181-211). New York, NY: John Wiley \& Sons, Inc.

Zellmer-Bruhn, M., \& Gibson, C. (2006). Multinational organization context: Implications for team learning and performance. Academy of Management Journal, 49(3), 501-518. 